\title{
DEVELOPING OF ENGLISH LANGUAGE PRINTED MATERIAL BASED ON 2013 CURRICULUM: ON GIVING EXPRESSION ABOUT CONGRATULATING AND COMPLIMENTING OTHERS
}

\author{
Ija Try Saputri Kadir \\ Universitas Negeri Makassar \\ ijatrysaputri@gmail.com \\ Kamsinah \\ Universitas Islam Negeri Alauddin Makassar \\ kamsinah@uin-alauddin.ac.id
}

\begin{abstract}
The research aims to develop English printed material of Giving Expression about Congratulating and Complimenting others based on 2013 curriculum of the English tenth grade students in SMA Negeri 16 Makassar. According to the interview with one of the English teachers in SMAN 16 Makassar that there are some problems according to the material and layout of the book. In addition, teacher in implementing 2013 curriculum was unprepared and the students faced difficulties in learning English since they didn't have many references except the students' book that was provided by the government. The research design used in this study was Research and Development (R\&D). The development model used was ASSURE model. The instruments used in this study were questionnaire and rubrics for the teacher, students, and experts. In this research, teacher and expert were involved in order to validate the product. There are four aspects of product validation. They are systematic organization of materials, systematic English teaching, systematic content of English, and the language. To sum-up, the result of this printed material analyzed by by the expert was well-qualified as on reference used in teaching English material. So, the product was expected to be able to help both the students and teachers in learning and teaching English especially Giving Expression about Congratulating and complimenting others material.
\end{abstract}

Keyword: Developing, Printed material, Expression about Congratulating and complimenting others material.

\section{A. INTRODUCTION}

I

$\mathrm{n}$ teaching and learning process in the classroom, including teaching English as a foreign language (TEFL). According to Chinoda (1982: 48) there are three main elements that support the effectiveness of a learning process; the teachers, the students, and the materials. As one of the main elements, the materials can be categorized into two major from i.e printed material and non-printed material.

According to Jurilla (2014) printed material is all written material, excluding non-print resources, which convey planned course information as a support for the teaching-learning process, such as textbook, handout, module, etc. In this case, the researcher develops one of 


\section{Ija Try Saputri Kadir, Kamsinah, Developing Of English Language...}

English language printed material such as book that is used in the tenth grade students based on 2013 curriculum.

Teaching English in Indonesia is currently based on curriculum. Curriculum is a basis of teaching-learning process, so every teaching-learning process has to follow the curriculum. It is the planned interaction of pupils with instructional content, materials, resources, and processes for evaluating the attainment of educational objectives. That is why every teacher has to understand and follow the current curriculum before planning and developing a kind of teachinglearning process and the material for the teaching-learning process.

The curriculum in Indonesia has been changing and developing in many times. Curriculum change happens with reasons and purposes, of course to make it more relevant. Curriculum change can answer the demands toward the education that must be able to adjust the evolving dynamics in society. Nowadays, The National Education Department has changed the previous curriculum - School Based Curriculum (SBC) 2006 with the new one called 2013. Curriculum The existence of 2013 curriculum becomes a great attention and leads to controversy for most people, because some people regard 2013 curriculum is not ready to be implemented. Not only that, in some English language teaching books, we still found problems in the teaching material. Through this problem teaching learning process will not become productive and conductive.

To clarify the issues, on 15 November 2016 the researchers had conducted a preliminary study by interviewing one of the English teachers of SMAN 16 Makassar to analyze the implementation of 2013 Curriculum especially in the tenth grade of Senior High School. Based on the researchers interview with Mrs. Ratna, there are so many problems according to the material and layout of the book. The researchers have found that the material is not appropriate such as the book the authors should preferably derived from expert. Besides, there are titles that do not correspond with the chapter, one example is a matter of talking about self, it is not in accordance with the topic. Likewise, should people talk when we want to practice listening to the native speaker. In addition, she also added the need for the addition of examples in each chapter so that students more easily understood and to understand the material. 
Volume 4, Number 01, June 2018

In the 2013 curriculum, the teachers have to design the material for teaching process based on the syllabus that already arranged by the government. The teaching plan must be more creative to attract the students. It is the challenge for the teachers to develop and repair the teaching material as well.

After the researcher know about the problem in this book, the researcher thinks to develop these materials to be better and more creative in learning process because to make the students interested to learn, the book must be easy to understand and teacher must have more references as a source for teaching material in order that the learning process is not monotone and makes the students enjoy learning the English material. Thus the researcher wants to design this book to correct the weaknesses found in the book.

This research focused on developing the English material dealing with 2013 curriculum and specifically for KD 3.2 \& 4.2 about Giving expression about Congratulating and Complimenting others as a step to reach a good and meaningful learning environment.

\section{B. LITERATURE REVIEW}

This part, the resercher consists of some previous related research findings and some pertinent idea, some of them are states below:

Norlina (2014) the study in entitled: "Pengembangan Bahan Ajar Bahasa Inggris Berbasis Multimedia Interaktif Kelas X Pulau Laut Timur Di Kota Baru Kalimantan” she said that based on the test results, English language teaching materials based interactive multimedia achieve valid criteria, attractive, effective and can be applied in teaching. It can be seen from the results of the validation test material ( $83 \%$ ) with a very valid criteria. the level of attractiveness of the product obtained an average percentage of $81.46 \%$ with interesting criteria, the effectiveness of the product is obtain with the percentage of 74,83 based learning activities of students and student learning outcomes.

Purnamasari (2015:94-97) conducted the research entitled "Developing English Material for Grade X Students of Beauty Study Program " Based on the results of the materials evaluation, the developed materials are considered appropriate. The developed materials have the characteristics as described in the following paragraphs. To give a brief picture about the content of the unit, there is a title at the very beginning. The next is Warm-Up. The task is designed to build 


\section{Ija Try Saputri Kadir, Kamsinah, Developing Of English Language...}

background knowledge of the students. The main part of the unit is Lesson Proper. The tasks are divided into two sections; spoken and written. The four skills are all integrated. The last part of the unit is Reinforcement. The reinforcement covers Homework, Review, Reflection and Vocabulary list. The final draft of the materials is in the Appendix.

Khasanah (2015:68) on her research "The Implementation of 2013 Curriculum by The English Teacher and its Barries (A Case Study at the 10 th Grade of SMA N Rembang in 2014/2015 Academic Year) concluded that: (1) The teaching learning planning which is covered in lesson plan used scientific approach based on almost all the principles of lesson plan arrangement mentioned in permendikbud of 2013 curriculum and syllabus. The barriers of this dimension are choosing the right method and making the right instrument of authentic assessment that will cooperate to cover three learning domains and to support the success of Core and Basic Competence interpretation in the learning process. (2) The teacher organized the teaching learning process based on the lesson plans that have been prepared. It used scientific approach well. (3) The learning evaluation is conducted by the teacher based on what is planned on the dimension of planning including the barriers that affect it. So, the biggest portion of evaluating is using non-authentic assessment that also gives the biggest emphasis on cognitive domain. It is not same as the mandate of 2013 curriculum in permendikbud to use authentic assessment.

Based on findings above, the researcher concludes that teaching Giving Expression about Congratulating and Complimenting others material needs good method and media to support the students in learning the topic as well as the teachers need an extra source exclude the teacher's book that is provided by the government. Hence, this research in the fact brought a good product as mention before which is able to help both the teachers and the students in teaching and learning process. The product became a printed material covered about Giving Expression about Congratulating and complimenting others material that the teachers may claim as sources in teaching English. The researcher will develop Giving Expression about Congratulating and complimenting others material that makes students to understand. 
Volume 4, Number 01, June 2018

\section{RESEARCH METHOD}

This research is Research and Development (R\&D). According to Sugiyono (2015: 407), a Research and development method is the research methods used to produce a particular product, and test to the product. To be able to produce specific research that is used needs analysis and to test the effectiveness of these products in order to function in the public, the research is needed to test the effectiveness of these products. In Research and Development (R\&D) have many models which can be applied by researchers such as ASSURE model, ADDIES' model, Borg\& Gall model, Dick and Carey model, Kemp model and many others. Based on those models stated previously, the researcher used ASSURE model because this model allows the use of external resources and technology other than simple lecturing using textbooks, focus on step by step instruction for instructors to see the pros and cons of the lesson, provides lesson planning foundation while allowing creativity from the instructors, students can use computer software to make revisions to their homework quickly and easily.

According to Kent L. Gustafson \& Robert Maribe Branch (2002:22) the ASSURE model is an instructional desiign model developed by Heinich, Molenda, Russel, and Smaldino: it guides instructors through the lesson design process by embarcing the use of technologies. ASSURE appreciates "students" learning styles and [draws] on constructivism where learners interact with others in their environment to build on previous knowledge.

\section{FINDINGS AND DISCUSSION}

\section{Findings}

a. The Result of Teacher Interview Related to the English Material that are Currently Used

The result of teacher interview, the teacher indicated that the teachers currently used single source from textbook only. This textbook is a compulsory one textbook provided by schools. The books are designed for fulfillment of 2013 curriculum.

In fact, there are many problems found in the book. As the teacher interview, the researcher identified several weaknesses in the existing teaching materials. Among them; the material contained in the book does not use local content, thus making it difficult for students to understand because it is not familiar to them. The materials provided also does not fit the needs 
Ija Try Saputri Kadir, Kamsinah, Developing Of English Language...

of students because too many exercises while very few examples, thus making students confused in doing the task.

b. The result of need analysis of materials based on the syllabus

The materials of giving expression about ccongratulating and complimenting others were developed in several subtopics. They are Excellent, Congratulation and Oh Great!. Every meeting had a core skill that was integrated one another in flows of skill that were arranged sistematically. Again, learning activities dealt with scientific approach included observing, questioning, collecting information, associating, and communicating. Last, the developed learning instruction referring to the type of activities was consisted of individual, pair, and group activitiy, the amount of activities, and text structure. These materials were developed in order to provide suitable materials for the Tenth grade Students in SMA Negeri 16 Makassar.

c. The result of analyze learners of developing learning materials based on the student's questioinaires.

Table 1

Result of Qquestionnaire Part A (General Characteristic)

\begin{tabular}{|c|c|c|c|}
\hline No. & Characteristics & Answer & Conclusion \\
\hline \multirow[t]{3}{*}{1.} & Amount of student & & \\
\hline & Male & 17 & \multirow[b]{2}{*}{ Most of the students are female } \\
\hline & Female & 18 & \\
\hline \multirow[t]{4}{*}{2.} & Address/Location & & \\
\hline & City & 32 & \multirow[b]{3}{*}{ Most of students live in the city } \\
\hline & Island & 2 & \\
\hline & Gowa & 1 & \\
\hline \multirow[t]{4}{*}{3.} & Previous School & & \\
\hline & Good Quality & 10 & \multirow{3}{*}{$\begin{array}{l}\text { Most of the students graduated from medium } \\
\text { quality school }\end{array}$} \\
\hline & Medium & 20 & \\
\hline & Low & 5 & \\
\hline
\end{tabular}


Volume 4, Number 01, June 2018

\begin{tabular}{|c|c|c|c|}
\hline \multirow[t]{4}{*}{4.} & Religion & & \\
\hline & Islam & 17 & \multirow{3}{*}{ Most of the students are Muslim } \\
\hline & Kristen protestan & 14 & \\
\hline & Katolik & 4 & \\
\hline \multirow[t]{5}{*}{5.} & Mother Tongue & & \\
\hline & Bahasa Indonesia & 33 & \multirow{4}{*}{$\begin{array}{l}\text { Most of the students mother tongue is Bahasa } \\
\text { Indonesia }\end{array}$} \\
\hline & Bahasa Makassar & 7 & \\
\hline & Bahasa Bugis & 1 & \\
\hline & Bahasa Jawa & 1 & \\
\hline \multirow[t]{7}{*}{6.} & Ethnic & & \\
\hline & Bugis & 1 & \multirow{6}{*}{ Most of the students is Makassar } \\
\hline & Makassar & 19 & \\
\hline & Polmas / mamasa & 3 & \\
\hline & Tanah Toraja & 7 & \\
\hline & Jawa & 1 & \\
\hline & Mixed Ethnic & 4 & \\
\hline \multirow[t]{6}{*}{7.} & Personal Gadget & & \\
\hline & Handphone & 5 & \multirow{5}{*}{$\begin{array}{c}\text { All the students have gadget, Smartphone is } \\
\text { the most }\end{array}$} \\
\hline & Smartphone & 27 & \\
\hline & Notebook & 2 & \\
\hline & Computer & 1 & \\
\hline & Tablet & 1 & \\
\hline \multirow[t]{3}{*}{8.} & Father Education & & \\
\hline & Elementary School & 3 & \\
\hline & Junior High School & 5 & \\
\hline
\end{tabular}


Ija Try Saputri Kadir, Kamsinah, Developing Of English Language...

\begin{tabular}{|c|c|c|c|}
\hline & Senior High School & 20 & \multirow[t]{3}{*}{$\begin{array}{c}\text { Most of their father are graduate from Senior } \\
\text { High School }\end{array}$} \\
\hline & Bachelor & 5 & \\
\hline & Master & 2 & \\
\hline \multirow[t]{6}{*}{9.} & Mother Education & & \\
\hline & Elementary School & 4 & \multirow{5}{*}{$\begin{array}{c}\text { Most of their mather are graduate from } \\
\text { Senior High School }\end{array}$} \\
\hline & Junior High School & 7 & \\
\hline & Senior High School & 17 & \\
\hline & D3 & 1 & \\
\hline & Bachelor & 6 & \\
\hline \multirow[t]{6}{*}{10.} & Parent Income & & \\
\hline & $100.000-500.000 \mathrm{~K}$ & 4 & \multirow{5}{*}{$\begin{array}{l}\text { Most of the students from High -Economic } \\
\text { Level }\end{array}$} \\
\hline & $500.000-1.000 .000 \mathrm{M}$ & 5 & \\
\hline & $1.000 .000-2.000 .000 \mathrm{M}$ & 9 & \\
\hline & $2.000 .000-5.000 .000 \mathrm{M}$ & 12 & \\
\hline & $5.000 .000-20.000 .000 \mathrm{M}$ & 5 & \\
\hline
\end{tabular}

In the part $A$, the researcher conclude that most of students are female, most of students live in the city, most of students graduated from medium quality school, most of the students are muslims, most of students mother tongue is bahasa Indonesia, most of the students ethnic is Makassar, all of the students have gadget but smartphone is the most, most of their father and mother graduate from senior high school, and most of the students from high-economic class level.

Furthermore, part B came into a conclusion as shown in a table below: 
Volume 4, Number 01, June 2018

Table 2

\section{Result of questionnaire Part B (Entry Competences)}

\begin{tabular}{|c|c|c|c|}
\hline No. & Questions & Answer & Conclusion \\
\hline \multirow{5}{*}{1.} & $\begin{array}{l}\text { Common Obstacle in } \\
\text { learning English }\end{array}$ & & \multirow{5}{*}{$\begin{array}{c}\text { Most of the student's obstacle in learning } \\
\text { English are difficulty in Lack of } \\
\text { knowledge in grammar and the limitation } \\
\text { of vocabulary }\end{array}$} \\
\hline & $\begin{array}{l}\text { The limitation of } \\
\text { Vocabulary }\end{array}$ & 13 & \\
\hline & $\begin{array}{c}\text { Lack of knowledge in } \\
\text { grammar }\end{array}$ & 18 & \\
\hline & $\begin{array}{l}\text { Difficulty in } \\
\text { pronunciation }\end{array}$ & 12 & \\
\hline & Other & 1 & \\
\hline \multirow{5}{*}{2.} & The most difficult skill & & \multirow{5}{*}{$\begin{array}{l}\text { Most of the students considered Listening } \\
\text { is the most difficult skill }\end{array}$} \\
\hline & Listening & 20 & \\
\hline & Speaking & 15 & \\
\hline & Reading & 3 & \\
\hline & Writing & 7 & \\
\hline \multirow{3}{*}{3.} & Join English Course & & \multirow{3}{*}{$\begin{array}{l}\text { Most of the students not join English } \\
\text { course }\end{array}$} \\
\hline & Yes & 8 & \\
\hline & No & 27 & \\
\hline \multirow{5}{*}{4.} & $\begin{array}{l}\text { Knowledge about } \\
\text { Expression of } \\
\text { Congratulating and } \\
\text { Complimenting Others }\end{array}$ & & \multirow{5}{*}{$\begin{array}{c}\text { Most of the students know about } \\
\text { expression of Congratulating and } \\
\text { Complimenting others }\end{array}$} \\
\hline & Really know & 7 & \\
\hline & Know & 24 & \\
\hline & Not Really & 3 & \\
\hline & Not Know & 1 & \\
\hline \multirow{3}{*}{5.} & $\begin{array}{l}\text { The way of learning } \\
\text { Expression of } \\
\text { Complimenting and } \\
\text { Congratulating Others }\end{array}$ & & \multirow{3}{*}{$\begin{array}{l}\text { Most of the students choose learn } \\
\text { Expression of Complimenting and } \\
\text { Congratulating Others in Direct }\end{array}$} \\
\hline & Direct & 28 & \\
\hline & Expression Card & 6 & \\
\hline
\end{tabular}


Ija Try Saputri Kadir, Kamsinah, Developing Of English Language...

\begin{tabular}{|c|c|c|c|}
\hline \multirow{2}{*}{} & Email/ Message & 8 & \multirow{4}{*}{} \\
\cline { 2 - 3 } & Others & 1 & \\
\hline
\end{tabular}

From the result of part B (Entry Competencies), the researcher conclude that; Most of the student's obstacle in learning English are difficulty in Lack of knowledge in grammar and the limitation of vocabulary, most of the students considered Listening is the most difficult skill, most of the students not join English course, Most of the students know about expression of Congratulating and Complimenting others.Most of the students choose learn Expression of Complimenting and Congratulating Others in Direct. Then, also the part $\mathrm{C}$ was found a data as shown in the table below;

Table 3

Result of Questionnaire Part C (Learning Style)

\begin{tabular}{|c|c|c|c|}
\hline No. & Characteristics & Answer & Conclusion \\
\hline \multirow[t]{7}{*}{1.} & Learning Style & & \multirow{5}{*}{ Most of the students is Audio } \\
\hline & Audio & 16 & \\
\hline & Visual & 7 & \\
\hline & Kinestetik & 5 & \\
\hline & Audio \& Visual & 2 & \\
\hline & Audio \& Kinestetik & 4 & \\
\hline & Visual \& Kinestetik & 1 & \\
\hline \multirow{4}{*}{2.} & Learning (Manner) & & \multirow{4}{*}{$\begin{array}{c}\text { Most the students choose group as } \\
\text { the most effective }\end{array}$} \\
\hline & Individual & 9 & \\
\hline & Pair & 14 & \\
\hline & Group & 18 & \\
\hline \multirow{2}{*}{3.} & Enthusiasm & & \multirow[b]{2}{*}{ The students enthusiasm withthe } \\
\hline & The Appearance of Learning & 14 & \\
\hline
\end{tabular}


Volume 4, Number 01, June 2018

\begin{tabular}{|c|c|c|}
\hline Material is Attractive & learning model is varied and different \\
from usual
\end{tabular}

Part C (Learning Style) consisted of 3 questions, as a conclusion found that the students were liked a learning style with audio style in the learning process. They also liked to do the project with a group, and when they were asked to present a learning material they would like to present it with their group. And the student's enthusiasm with the learning model is varied and different from usual.

3) The result of need analysis of Expert judgment suggestion

The questionnaire that used by the researcher to analyze the students' needs ware originally designed. At the first time, it was designed by deciding the components that would be put on the questionnaire until it done with four parts. The first part consisted of six questions related to the systematic organization of materials, the point of the questions was to know the target of the materials systematic. Furthermore, in the second part that consisted of one questions related to the systematic English teaching, these questions were pointed to know the activities are attractive and motivate the learners in order to achieve the target in designing the materials that applicable for the students. Then, in the third part that consisted of three questions, the point of these questions was to know the systematic content of English. The last part is about the language, the point are to know the level of accuracy, clarity and the understandable the language used.

\section{a. State Objective}

In this step, emphasizes the need to state the desired outcomes of instruction in specific and measurable terms. A rationale for stating measurable objectives is presented, including their role strategy and media selection, assessment of learning, and communicating the intent of the instruction to learners. 
Ija Try Saputri Kadir, Kamsinah, Developing Of English Language...

b. The Result of the Select Media and Materials

1) Content Materials

2) Primary Skill

3) Scientific Approaches

4) Learning Instruction

c. The Result of Utilize Media \& Material

1. Reviewing the materials

2. Preparing the material

3. Preparing the environment

4. Preparing the students

5. Ensuring a learning experience

\section{d. The Result of Require Learner Participation}

In this step, the researcher writes down the activities according to the product with time allocation each activity, type of activity, and also what kind of exercises use in the product.

\section{Table 4}

The Activity in Require Learner Participation

Topic 1, Excellent, Congratulation!

\begin{tabular}{|l|l|l|}
\hline \multicolumn{1}{|c|}{ Time Alocation } & $\begin{array}{l}\text { Type of } \\
\text { activity }\end{array}$ & Model of Excercise \\
\hline $\mathbf{1 0}$ minutes & $\begin{array}{l}\text { Individual, } \\
\text { answer } \\
\text { questions }\end{array}$ & Questionning \\
\hline $\mathbf{1 0}$ minutes & Individual & $\begin{array}{l}\text { Listen \& Repeat congratulations } \\
\text { card }\end{array}$ \\
\hline $\mathbf{5}$ minutes & Listening & $\begin{array}{l}\text { Listen \&identify the types of } \\
\text { congratulations card }\end{array}$ \\
\hline $\mathbf{5}$ minutes & $\begin{array}{l}\text { Find the } \\
\text { meaning of } \\
\text { the word in }\end{array}$ & Find Indonesian Meaning \\
\hline
\end{tabular}


Volume 4, Number 01, June 2018

\begin{tabular}{|c|c|c|}
\hline Vocabulary & the table & \\
\hline $\begin{array}{l}5 \text { minutes } \\
\text { Vocabulary }\end{array}$ & Pair, & $\begin{array}{l}\text { complete the following dialogue } \\
\text { with the suitable expressions. }\end{array}$ \\
\hline $\begin{array}{l}5 \text { minutes } \\
\text { Reading }\end{array}$ & $\begin{array}{l}\text { Pair, Read } \\
\text { dialogue }\end{array}$ & Read the dialogue with partnert \\
\hline $\begin{array}{l}5 \text { minutes } \\
\text { Reading }\end{array}$ & Pair, & $\begin{array}{l}\text { Identify the expressions of } \\
\text { congratulation and response } \\
\text { from the dialogue }\end{array}$ \\
\hline $\begin{array}{l}5 \text { minutes } \\
\text { Speaking }\end{array}$ & Individual & $\begin{array}{l}\text { Study the explanations about } \\
\text { expression of congratulation }\end{array}$ \\
\hline $\begin{array}{l}15 \text { minutes } \\
\text { Speaking }\end{array}$ & Group & $\begin{array}{l}\text { Discuss how you express } \\
\text { congratulation for the situations } \\
\text { and report the results of your } \\
\text { discussion in front of the class. }\end{array}$ \\
\hline $\begin{array}{l}20 \text { minutes } \\
\text { Speaking }\end{array}$ & $\begin{array}{l}\text { Group, Role } \\
\text { play }\end{array}$ & $\begin{array}{l}\text { Choose one of these role play } \\
\text { cards then make a dialogue based } \\
\text { on the situations }\end{array}$ \\
\hline $\begin{array}{l}10 \text { minutes } \\
\text { Writing }\end{array}$ & Group & $\begin{array}{l}\text { Give the most appropriate } \\
\text { expression and response of } \\
\text { congratulation based on the } \\
\text { pictures below and write on your } \\
\text { book }\end{array}$ \\
\hline $\begin{array}{l}20 \text { minutes } \\
\text { Writing }\end{array}$ & Group & Write congratulation Cards \\
\hline $\begin{array}{l}5 \text { minutes } \\
\text { Reflection }\end{array}$ & Individual & Self Reflection \\
\hline
\end{tabular}

Topic 2, Oh Great! 
Ija Try Saputri Kadir, Kamsinah, Developing Of English Language...

\begin{tabular}{|c|c|c|}
\hline Time Allocation & Type of activity & Model of Exercise \\
\hline $\begin{array}{l}10 \text { minutes } \\
\text { Warming Up }\end{array}$ & $\begin{array}{l}\text { Individual, answer } \\
\text { questions }\end{array}$ & Questionning \\
\hline $\begin{array}{l}5 \text { minutes } \\
\text { Pronunciation }\end{array}$ & Individual practice & $\begin{array}{l}\text { Listen and Pronounce } \\
\text { Vocabulary }\end{array}$ \\
\hline $\begin{array}{l}5 \text { minutes } \\
\text { Pronunciation }\end{array}$ & Individual practice & $\begin{array}{l}\text { find the meaning of } \\
\text { word in the table }\end{array}$ \\
\hline $\begin{array}{l}10 \text { minutes } \\
\text { Vocabulary }\end{array}$ & Individual & $\begin{array}{l}\text { Find Indonesian } \\
\text { Equivalent of } \\
\text { vocabulay }\end{array}$ \\
\hline $\begin{array}{l}15 \text { minutes } \\
\text { Reading }\end{array}$ & Pair & $\begin{array}{l}\text { Read the conversation } \\
\text { and identify } \\
\text { expression of } \\
\text { complimenting and } \\
\text { response from the } \\
\text { dialogue }\end{array}$ \\
\hline $\begin{array}{l}15 \text { minutes } \\
\text { Reading }\end{array}$ & Individual & $\begin{array}{l}\text { Read the conversation } \\
\text { and answer the } \\
\text { questions. }\end{array}$ \\
\hline $\begin{array}{l}5 \text { minutes } \\
\text { Speaking }\end{array}$ & Individual & $\begin{array}{l}\text { study the explanation } \\
\text { about complimenting } \\
\text { and response }\end{array}$ \\
\hline $\begin{array}{l}15 \text { minutes } \\
\text { Speaking }\end{array}$ & Group & $\begin{array}{l}\text { discuss how to give } \\
\text { and respond } \\
\text { compliments based } \\
\text { on the situations and } \\
\text { practice in front of } \\
\text { the class. }\end{array}$ \\
\hline 5 minutes & Individual & $\begin{array}{l}\text { Analyze to the tense } \\
\text { used in the }\end{array}$ \\
\hline
\end{tabular}


Volume 4, Number 01, June 2018

\begin{tabular}{|c|c|c|}
\hline Grammar review & & compliment card \\
\hline $\begin{array}{l}10 \text { minutes } \\
\text { Grammar review }\end{array}$ & Individual & $\begin{array}{l}\text { make a } \\
\text { complimenting card } \\
\text { using present tense }\end{array}$ \\
\hline $\begin{array}{l}10 \text { minutes } \\
\text { grammar review }\end{array}$ & Individual & $\begin{array}{l}\text { arrange the words to } \\
\text { make sentences }\end{array}$ \\
\hline $\begin{array}{l}5 \text { minutes } \\
\text { Grammar review }\end{array}$ & Individual & $\begin{array}{l}\text { Analyze to the tense } \\
\text { used in the } \\
\text { compliment card }\end{array}$ \\
\hline $\begin{array}{l}10 \text { minutes } \\
\text { grammar review }\end{array}$ & Individual & $\begin{array}{l}\text { make a } \\
\text { complimenting card } \\
\text { using past tense. }\end{array}$ \\
\hline $\begin{array}{l}10 \text { minutes } \\
\text { Role play }\end{array}$ & Group & $\begin{array}{l}\text { act out dialogue based } \\
\text { on the following } \\
\text { situations. }\end{array}$ \\
\hline $\begin{array}{l}5 \text { minutes } \\
\text { Writing }\end{array}$ & Individual & $\begin{array}{l}\text { Write the most } \\
\text { appropriate } \\
\text { expression of } \\
\text { compliment based on } \\
\text { pictures. }\end{array}$ \\
\hline $\begin{array}{l}\mathbf{1 0} \text { minutes } \\
\text { writing (lets play } \\
\text { game) }\end{array}$ & Group & $\begin{array}{l}\text { give compliment and } \\
\text { response with friends }\end{array}$ \\
\hline $\begin{array}{l}5 \text { minutes } \\
\text { Reflection }\end{array}$ & Individual & Reflection \\
\hline
\end{tabular}


Ija Try Saputri Kadir, Kamsinah, Developing Of English Language...

\section{e. The Result of Evaluate and Revise}

1) The Result of Development of Rubric for Expert and Teacher.

This section presented some aspects about giving expression about Congratulating and complimenting others. They included the systematic organization of material, systematic of English teaching, and systematic content of English. There is an answer score with criteria based on the Like Scale as modified as follows;

a) The Criteria Score of Expert Rubric

Find the highest score by

Highest score $=$ Number of V alidator $\times$ Maximum Score

$$
\begin{aligned}
& =3 \times 4 \\
& =12
\end{aligned}
$$

b) Determination of The $V$ alue of $V$ alidity by Means

Validity value $=\frac{\text { Number of scores obtained }}{\text { Maximum score }} \times 100$.

In $100 \%$

$90-100=$ Very Valid

80-89= Valid

60-79= Quite Valid

$0-59=$ Invalid

Provide an assessment of validity value with criteria such as the following:

Table 4.5

The Result of Expert Rubric Validity

\begin{tabular}{|c|c|c|c|c|c|c|}
\hline Criteria & $\begin{array}{c}\text { Expert } \\
1\end{array}$ & $\begin{array}{c}\text { Expert } \\
2\end{array}$ & $\begin{array}{c}\text { Expert } \\
3\end{array}$ & $\begin{array}{c}\text { Total } \\
\text { score }\end{array}$ & $\begin{array}{c}\text { Validity } \\
\text { Value }\end{array}$ & Validity \\
\hline 1 & 4 & 1 & 4 & 9 & 75 & QV \\
\hline 2 & 4 & 3 & 4 & 11 & 91.67 & VV \\
\hline 3 & 3 & 4 & 3 & 11 & 91.67 & VV \\
\hline
\end{tabular}


Volume 4, Number 01, June 2018

\begin{tabular}{|c|c|c|c|c|c|c|}
\hline 4 & 4 & 4 & 3 & 11 & 91.67 & VV \\
\hline 5 & 3 & 4 & 4 & 11 & 91.667 & VV \\
\hline 6 & 3 & 2 & 4 & 9 & 75 & QV \\
\hline 7 & 4 & 2 & 4 & 10 & 83.333 & $\mathrm{~V}$ \\
\hline 8 & 4 & 3 & 4 & 11 & 91.67 & VV \\
\hline 9 & 4 & 3 & 4 & 11 & 91.67 & VV \\
\hline 10 & 4 & 3 & 4 & 11 & 91.67 & VV \\
\hline 11 & 4 & 3 & 3 & 10 & 83.333 & $\mathrm{~V}$ \\
\hline 12 & 3 & 4 & 4 & 11 & 91.67 & VV \\
\hline 13 & 4 & 4 & 4 & 12 & 100 & VV \\
\hline 14 & 4 & 4 & 3 & 11 & 91.67 & VV \\
\hline 15 & 4 & 3 & 3 & 10 & 83.333 & $\mathrm{~V}$ \\
\hline 16 & 4 & 4 & 4 & 12 & 100 & VV \\
\hline 17 & 3 & 3 & 3 & 9 & 75 & QV \\
\hline 18 & 4 & 3 & 4 & 11 & 91.67 & VV \\
\hline 19 & 4 & 4 & 3 & 11 & 91.67 & VV \\
\hline 20 & 4 & 4 & 4 & 12 & 100 & VV \\
\hline 21 & 4 & 4 & 3 & 11 & 91.67 & VV \\
\hline 22 & 4 & 1 & 4 & 9 & 75 & QV \\
\hline 23 & 4 & 3 & 4 & 11 & 91.67 & VV \\
\hline 24 & 4 & 4 & 4 & 12 & 100 & VV \\
\hline 25 & 4 & 3 & 4 & 11 & 91.67 & VV \\
\hline 26 & 4 & 3 & 3 & 10 & 83.333 & $\mathrm{~V}$ \\
\hline 27 & 3 & 3 & 4 & 10 & 83.333 & $\mathrm{~V}$ \\
\hline 28 & 4 & 3 & 4 & 11 & 91.67 & VV \\
\hline 29 & 4 & 3 & 4 & 11 & 91.67 & VV \\
\hline 30 & 4 & 3 & 3 & 10 & 83.333 & V \\
\hline
\end{tabular}


Ija Try Saputri Kadir, Kamsinah, Developing Of English Language...

\begin{tabular}{|c|c|c|c|c|c|c|}
\hline 31 & 4 & 3 & 3 & 10 & 83.333 & $\mathrm{~V}$ \\
\hline 32 & 4 & 3 & 4 & 11 & 91.67 & $\mathrm{VV}$ \\
\hline 33 & 3 & 2 & 4 & 9 & 75 & QV \\
\hline 34 & 4 & 2 & 4 & 10 & 83.333 & $\mathrm{~V}$ \\
\hline 35 & 4 & 3 & 3 & 10 & 83.333 & $\mathrm{~V}$ \\
\hline 36 & 4 & 3 & 3 & 10 & 83.333 & $\mathrm{~V}$ \\
\hline 37 & 4 & 3 & 4 & 11 & 91.67 & $\mathrm{VV}$ \\
\hline
\end{tabular}

The components of the teaching materials 3.4 and 4.4 competences that developed as a printed material already shown and checked by the expert and again to validate the learning materials expert used the instrument of learning material analysis. The learning material analysis used was the standard one, where there approximately four items marked then the printed material validated.

\section{2) The Result of Development and Expert Judgment Suggestion}

Considering of the teaching materials that developed, the expert found some grammatical errors and misspelling words in the product especially in the instruction. The expert also told the researcher to use the simple language in the content of materials. In addition, the expert asked the researcher to give an example in some exercises. Forward, the expert said that the researcher should consider about the time allocation every activity.

\section{Discussion}

Curriculum is a variable that will significantly impact on decisions about designing materials for teaching. Many teachers are bound by a mandated curriculum defining the contents, skills, and values to be taught. Whether imposed at school or state level, a curriculum outlines the goals and objectives for the learners and the course of study. Whatever the curriculum, it is the teacher's responsibility to ensure that the goals and objectives of the overarching curriculum are kept close at the hand when designing materials (Nunan, 1988) Furthermore, the curriculum in Indonesia already experienced several changes and the latest one was called 2013 Curriculum or abbreviated with $\mathrm{K}-13$. 
Volume 4, Number 01, June 2018

1. The obstacles on implementing the K-13

The government of the Republic of Indonesia represented by the Ministry of Education and Culture has stipulated that the new curriculum, K-13 should be implemented in all levels of education all over Indonesia starting from 2013-2014 academic year. This change, of course, result in a number of consequences for the stakeholders. One of the stakeholders that directly experience the consequences most is the teacher. Below are several obstacles on implementing the K-13:

a. The teachers who have begun to feel convenient and be accustomed to with the implementation of the School-Based Curriculum (SBC), suddenly have to shift their mind and teaching practices to this new curriculum. (Abdul Muth'im, 2014).

b. The central government through Ministry of Education and Culture provided English textbook both for the teacher (teacher's book) and student (student's book) but the materials of the books were difficult to understand by the students.

c. The main problem is that the teachers have to design the materials for teaching and learning process based on the syllabus that already arranged by the government.

\section{Designing English Materials for Teaching Giving Expression about congratulating and complimenting others dealing with K-13}

In designing English Teaching Materials may range from one-off, single use items to extensive programs of work where the tasks and activities build on each other to create a coherent progression of skills, concepts, and language items. Moreover, in 2013 curriculum or K13 , it was arranged that the components of the materials should apply the syllabus, where core competences must be achieved. Furthermore, this research was done with a product called Module where arranged based on K-13 and based on the students' need.

\section{E. CONCLUSION}

After conducting the research and doing data analysis, the researcher derived conclusion in this three following points :

Now days, the material used at SMAN 16 Makassar was text book only that provided by government as their source in teaching and learning process. So, that many students found the difficulties in learning English. Therefore, the researcher developed material in this case giving 


\section{Ija Try Saputri Kadir, Kamsinah, Developing Of English Language...}

announcement based on 2013 curriculum at the teaching and learning material for the teacher and students at SMAN 16 Makassar.

The product was developed based on the result of the analysis of the questionnaire that distributed to the students in tenth grade students in SMAN 16 Makassar where the aim of the questionnaire was to know the students' general characteristic, entry competencies, and learning style. Based on try-out, the researcher concludes that the product giving satisfactory. Moreover, the material in the product more variety.

Based on the findings and discussions of the research that has been done, and are associated with the formulation of the research focus, it can be concluded that the systematic organization of developing giving expression about congratulating and complimenting others materials dealing with 2013 Curriculum already checked by the expert in order to validate the whole materials in a printed material and claimed that it was validated by the expert.

\section{REFERENCES}

Ahmad, D., \& Nur, H. K. (2015). Developing English Lesson Plans For The First Year Students Of Sma 18 Makassar Based On The 2013 Curriculum. ETERNAL (English, Teaching, Learning, and Research Journal), 1(2), 187-200.

Abdul Muth'im, (2014) “ Revitalization Of English Teacher Education: An Effort To Improve The Quality Of Students' Learning In English”, Articles (English Educational Program Lambung Mangkurat University Banjarmasin Indonesia.

Badruddin, D. (2015). Developing A Task-Based Syllabus Based On Needs Analysis For Midwifery At Uin Alauddin Makassar. ETERNAL (English, Teaching, Learning, and Research Journal), 1(1), 112-130.Branch, Robert Maribe \& Gustafson, Kent L. 2002. Survei of Instructional Models.New York: Syracuse University.

Brian, Tomlinson. (2011) Materials Development in Language Teaching.United Kingdom: Cambridge University Press..

Chinoda, A.M. (1982) An Analysis of Questions Selected From Senior High Social Studies Textbook Used In Zimbabwe. Diss. George Peabody College. 
Volume 4, Number 01, June 2018

Ganjarsari. (2015) Developing The Song To Teach Language Components for The Sevents Grades of Smp Wahid Hasyim Malang. Thesis. Universitas Negeri Malang

Hikmawati, M., \& Ahmad, D. (2017). Developing Greeting And Self Introducing Materials Dealing With 2013 Curriculum Of The Seventh Grade In Mtsn Balang-Balang. ETERNAL (English, Teaching, Learning, and Research Journal), 3(2), 124-135.

Han, Lixin. (2000) “The ASSURE Model: Integrating Technology into Learning”. University of Victoria.

Irawati. (2006) Improving the Reading Comprehension of the First Year Students of Sma Negeri 1 Makassar Through Communicative Tasks. Thesis. Makassar: School of Graduate studies,State University of Makassar.

Jurilla, Jenelyn. (2014) PrintedMaterial. Prezi, http://prezi.com/m/0kzp6at3hwzc/printedmaterials/

Khasanah (2015) Irma Nur. The Implementation of 2013 Curriculum By The English Teacher \& Its Barriers (A Case Study at The 10 th Grade of SMA N 1 Rembang in 2014/2015 Academic Year), Thesis. Semarang: Education and Teacher Training, Faculty Walisongo State Islamic University Semarang.

Limpo, Ridwan. (2016) Developing Descriptive Text Materials Dealing with 2013 Curriculum of the Seventh Grade in MTsN. Balang-Balang.Thesis. Makassar: School of Graduate Studies,State Islamic University of Alauddin.

“Learnenglishyeyeye", https://learnenglishyeyeye.wordpress.com/august/materialcongratulation/ Accessed on November 10 $0^{\text {th }}, 2016$.

Mahirah, R., Ahmad, D., \& others. (2016). Designing Multiple Choice Test Of Vocabulary For The First Semester Students At English Education Department Of Alauddin State Islamic University Of Makassar. ETERNAL (English, Teaching, Learning, and Research Journal), 2(2), 194-208.

Marshan, S. (2015). Developing English Morphology Materials For Undergraduate Students At Alauddin State Islamic University Of Makassar. ETERNAL (English, Teaching, Learning, and Research Journal), 1(1), 1-14.

Mubar, M. K. N. A. (2015). Developing English Learning Materials For Young Learners Based On Needs Analysis At Mtsn Model Makassar. ETERNAL (English, Teaching, Learning, and 
Ija Try Saputri Kadir, Kamsinah, Developing Of English Language...

Research Journal), 1(2), 313-330.

Matthew B. Miles And A. Michael Huberman. (1994) “Qualitative Data Analysis” 2nd Edition; Sage Publications.

Malik Ibrahim, Misykat. Implementasi Kurikulum 2013 (Rekonstruksi Kompetsi,Revolusi pembelajaran dan Reformasi penilaian ). Makassar: Alauddin University Press.

Mharjay A Delacrus, (2015) Effect of Lack on Instructional Material, Bulacan State University:

Nurpahmi, S. (2013). An Introduction to English for Specific Purposes. Makassar: Alauddin University Press.

Nurpahmi, S. (2014). English for Sepecific Puposes: An Integrated Approach. Makassar: ALauddin University Press.

Nurpahmi, S. (2017). ESP Course Design: An Integrated Approach. Lentera Pendidikan: Jurnal Ilmu Tarbiyah Dan Keguruan, 19(2), 172-181.

Norlina, Hariani. (2014) Pengembangan Bahan Ajar Bahasa Inggris Berbasis Multimedia Interaktif Kelas

X Pulau Laut Timur Di Kota baru Kalimantan Selatan.Thesis. Malang: Program Studi Pendidikan

Teknologi Pendidikan Program Pasca Sarjana Universitas Negeri Malang.

Purnamasari, Yohana Dian Ratna. (2015) Developing English Learning Material for Grade X Students of Beauty Study Program, Thesis. Yogyakarta: English Education Department, University of Yogyakarta.

Rohmah, Choirul. (2015) Developing English learning materials for grade $x$ students of marketing study program at smk muhammadiyah 2 bantul. Thesis. Yogyakarta: English Education Department, University of Yogyakarta.

Sugiyono.(2015) MetodePenelitianPendidikan: PendekatanKuantitatif, Kualitatif, dan R\&D. Bandung: Alfabeta.

Widya, Yank. (2013). Bahan ajar cetakdan non cetak. Accessed from 16 july 2017. Post on 14 october. https://www.scribd.com/doc/176007491/Bahan-Ajar-Cetak-Dan-Non-Cetak. 